\title{
CLIMATE CHANGE AND THE AVAILABILITY OF WATER RESOURCES IN BENIN
}

Mudanças climáticas e disponibilidade de recursos em água no Benin

\author{
Pr. Michel BOKO \\ Dr. Ernest AMOUSSOU \\ Dr Henri TOTIN \\ Rufine A. SEDJAME
}

Laboratory Pierre PAGNEY, (Climate, Water, Ecosystems, and Development)

Abomey-Calavi University, 03 P.O. Box 1122, Cotonou-03 (Rep. of Benin)

\begin{abstract}
It is likely that climate change in the coming decades, even very few, will produce more important impacts on thesocio-economic systems than in the past, due to the growth in world population and the increasing sophistication of technology and development issues (Issa, 1995). According to UNESCO (2006), climate change will be responsible for $20 \%$ of the worsening water scarcity in the world. This looming water crisis will be induced by changes in the parameters that determine the water cycle (Totin, 2005). The study is based on analysis of a baseline from which the main meteorological parameters (rainfall, flow, etc.) are projected to 2025 time horizon. It corresponds to the horizon of the prospective study for 2025 in Benin. From these basic parameters, the main elements to characterize water resources (such as infiltration, the volume of water available water bodies, etc.) were determined for each time horizon. Research carried out in different regions of the Benin on climate issues, surface and ground water (Gbatcho 1992; Boko, 1998; Boukari, 1998 Linsoussi, 2000; Sadji, 2004; Amoussou, 2003 and 2005; Totin, 2003 and 2005; Tossa, 2005; Vissin et al., 2006 ; Vissin, 2001 and 2007 ; Alassane and Boukari, 2007; Idiéti, 2009 ; Totin, 2009) attest ruptures occurred in hydro-climatic chronicles during the 1970s and indicate a downward trend in superficial water resource two to four folds greater than that of rainfall in key watersheds. Similarly, the aquifers record deficit on refill aquifers (Boukari, 1998; Totin, 2005) and a variation of hydro-chemical caracteristics (Alassane, 2004). If this climate and hydrological trend continues, hydrological drought will lead to a considerable reduction of water resources and a potential shortage. Similarly, the water quality will be affected in various ways. Very wet weather events would induce an increased transfer of pollutants to the water bodies as opposed to dryness that would accentuate deterioration especially of the bacteriological quality of water resources. Facing to the quantitative and qualitative degradation of both surface and groundwater should develop strategies to increase the potential availability of the resource. To this end, it is important above all to protect areas of groundwater recharge, stabilize stream banks and water bodies. Improving the quality of water resources in a changing climate context implies that people are aware of the risks of shortage and of agricultural good practices (no use of chemical fertilizers and synthetic pesticides), management of solid and liquid waste. The water law must be adapted to the context of climate change and vulnerability of the water resource.
\end{abstract}

Keywords: climate change scenario, water resources, water law, Benin.

MUDANCCAS CLIMATICAS E DISPONIBILIDADE DE RECURSOS EM AGUA NO BENIN

RESUMO: É provável que a mudança climática nas próximas décadas, mesmo muito poucas, vai produzir impactos mais importantes nos sistemas socioeconômicos do que no passado, devido ao crescimento da população mundial e a crescente sofisticação da tecnologia e desenvolvimento de produtos (Issa, 1995). De acordo com a UNESCO (2006), a mudança climática será responsável por $20 \%$ da piora da escassez de água no mundo. Esta crise da água se aproximando será induzida por mudanças nos parâmetros que determinam o ciclo da água (Totin, 2005). O estudo é baseado na análise de uma linha a partir da qual os principais parâmetros meteorológicos (precipitação, vazão, etc) são projetados para o horizonte de tempo de 2025. Corresponde ao horizonte do estudo prospectivo para 2025 no Benin. A partir desses parâmetros básicos, os principais elementos para caracterizar os recursos hídricos (como infiltração, o volume de corpos hídricos disponíveis de água, etc) foram determinados para cada horizonte de tempo. As pesquisas realizadas em diferentes regiões do Benin sobre as questões climáticas, águas superficiais e subterrâneas (Gbatcho 1992; Boko, 1998; Boukari, 1998 Linsoussi, 2000; Sadji, 2004; Amoussou, 2003 e 2005; Totin, 2003 e 2005; Tossa, 2005; Vissin et al., 2006; Vissin, 2001 e 2007; Alassane e Boukari, 2007; Idiéti, 2009; Totin, 2009) atestam rupturas ocorreram em crônicas hidroclimáticas durante os anos 1970 e indicam uma tendência de queda na água superficial dos recursos de dois a quatro vezes maior do que a precipitação em bacias hidrográficas importantes. Da mesma forma, o déficit recorde de aquíferos em aquíferos de recarga (Boukari, 1998; Totin, 2005) e uma variação de características hidro químicas (Alassane, 2004). Se esta tendência climática e hidrológica continua, a seca hidrológica vai levar a uma redução considerável dos 
recursos hídricos e uma potencial escassez. Do mesmo modo, a qualidade da água vai ser afetada de várias maneiras. Eventos muito úmidos induziriam a um aumento da transferência de poluentes para as massas de água em oposição a secura que acentuaria a deterioração especialmente da qualidade bacteriológica dos recursos hídricos. Diante da degradação quantitativa e qualitativa das águas de superfície e subterrâneas deve-se desenvolver estratégias para aumentar o potencial de disponibilidade do recurso. Para este fim, é importante acima de tudo para proteger as áreas de recarga de águas subterrâneas, estabilizar córregos e corpos d'água. A melhoria da qualidade dos recursos hídricos em um contexto de mudança climática implica que as pessoas estejam cientes dos riscos de escassez e de boas práticas agrícolas (sem o uso de fertilizantes químicos e pesticidas sintéticos), gestão de resíduos sólidos e líquidos. A lei de água deve ser adaptada ao contexto da mudança climática e da vulnerabilidade dos recursos hídricos.

Palavras-chave: Cenário das alterações climáticas, recursos hídricos, Lei da Água, Benim.

\section{INTRODUCTION}

Water resources are essential for the social, economic, and even political growth of any nation. They are the basic strength of the emergence of African countries in general, and the one of Benin in particular where agriculture, cattle breeding, and fishing mainly lead the economy. Unfortunately, the deterioration of the climate has greatly affected these resources for the past years having an impact on the development process. To face the harmful effects of the climate change on water resources, it is essential to evaluate locally its severity. According to Bonell (2001), current global change is of a growing concern regarding the impact of climate variability and climate change on water resources. Indeed, the latter is continuously becoming poorer in terms of both quantity and quality as its atmospheric, surface and ground availability is influenced by climate variability and by management practices.

It is likely that the coming decades' climate variations, however slight, will produce on the socio-economic systems that are more important effects than the past, due to the world population growth and to the growing sophistication of the technologies and development issues (Issar, 1995). That is what UNESCO (2003) confirms by asserting that climatic changes will be responsible for $20 \%$ of the worsening of water scarcity in the world. This predicted water crisis will be induced by the variations of the climatic parameters such as rainfall, temperature, and evapotranspiration that determine water cycle process (Totin, 2005).

This paper helps to know better the linkages between climate change and water availability in Benin, water access issues, potential impacts of climate changes, corrective strategies, and perspectives.

\section{THE METHODOLOGICAL APPROACH USED}

The study is based on the analysis of a reference situation (basic scenario) from which the main meteorological parameters (rainfall, rate of flow, etc.) are forecast for the year 2025. It corresponds to the time period of the prospective study 2025 for Benin. From these basic parameters, the main elements helping to characterize water resources (like seepages, volumes of water available in the basins, etc.) have been determined for each temporal horizon. The bibliographic analysis has helped to understand the relation between climate change and water resources (groundwater and surface water) and to define better the problems related to Benin populations' access to water resources. The same approach has been used for climate projections formulated in the climate change scenario for Benin. The comparison of the impacts, regarding the horizon considered, has helped to determine the impacts of a climate change scenario for Benin and to suggest appropriate adaptation measures to overcome the harmful effects. 


\section{WATER RESOURCES IN AFRICA AND IN BENIN}

Most of water resources used in Africa in general and in Benin in particular come from rainfall, surface water bodies (lake, stream, pond, river, water reservoir) and ground water through wells, drillings, and springs.

The countries of the Gulf of Guinea, of which Benin is part and parcel, profit from favorable climatic conditions with great annual rainfall amount (figure 1 ) that favor the abundance of water resources.

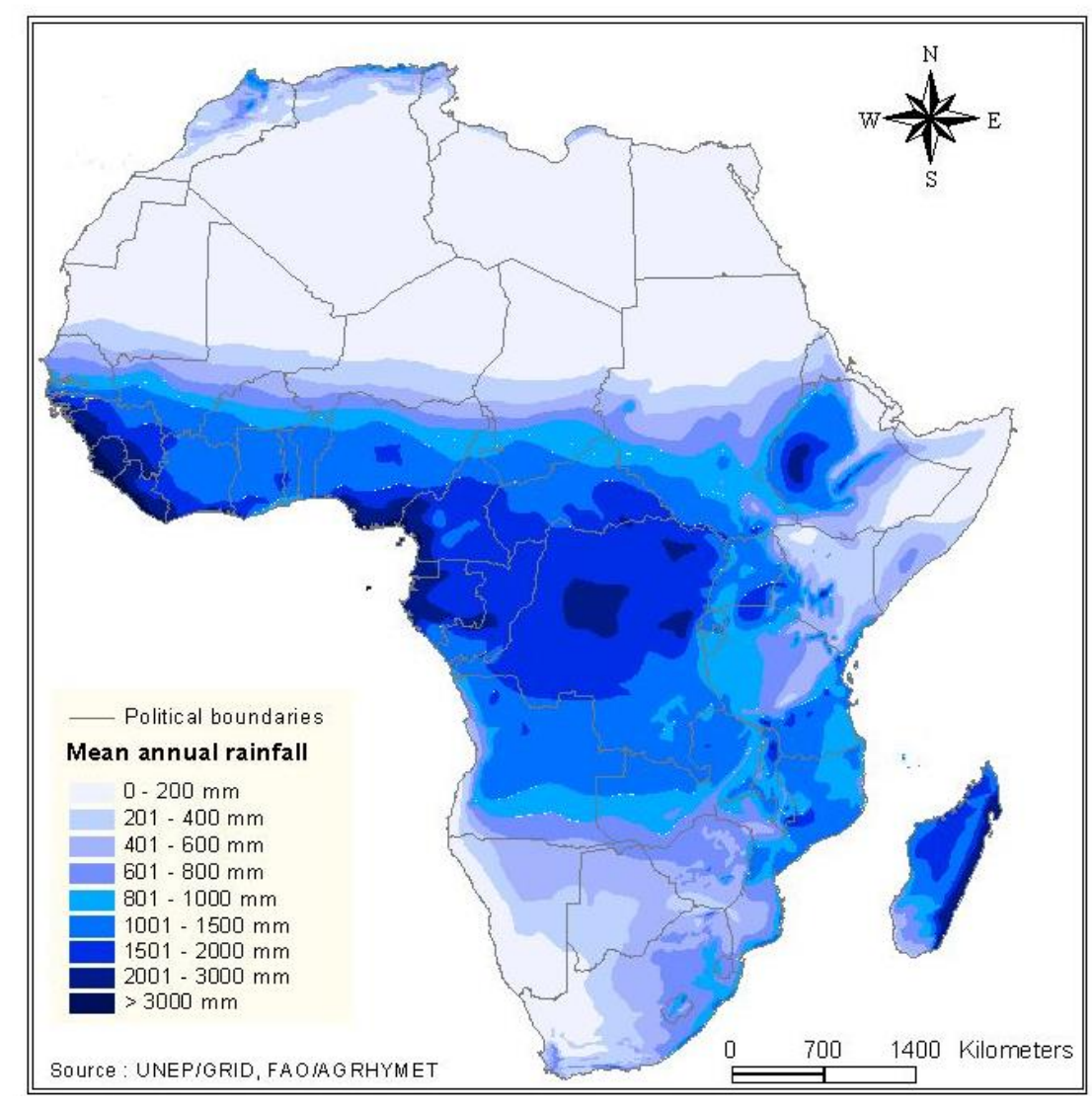

Figure 1 : Water Resource in Africa and the situation in the Gulf of Guinea

According to Soliman (2001) and FAO (1987), the average rainfall in Africa amounts to $694 \mathrm{~mm}$, that is about 21000 billion of cubic meters, of which $25 \mathrm{~mm}$ (ie 700 billion of cubic meters) join the groundwater resources; the surface water resources catch up to $75 \mathrm{~mm}$, which corresponds to 2280 billion of cubic meters.

Thus, Benin gets important water resources, which, should help to parry any difficulty related to needs satisfaction in the coming decades, if better managed. Water resources drained by the main country's watercourses amount to 13.106 billion of cubic meters yearly (Table 1), without taking into account the main course of Niger River as well as the ones of Sazué and the upper basins of Kéran and Kara.

This estimation has been made downstream water the hydrometric stations and is based on their average inter-annual modules calculated over observation periods varying from 22 to 48 years. 
Among the water bodies, there are Ahémé Lake and Nokoué Lake, which during high waters, store respectively 147 million and 325 million of cubic meters, and three lagoon systems (western, central, and eastern) and Porto-Novo Lagoon.

\begin{tabular}{|c|c|c|c|c|}
\hline Basin & Station & $\begin{array}{l}\text { Basins at the } \\
\text { station }\left(\mathrm{km}^{2}\right)\end{array}$ & $\begin{array}{c}\text { Average over } \\
\text { the period in } \\
\text { cubic meters } \\
\text { /s }\end{array}$ & $\begin{array}{c}\text { Volume } \\
\text { (in millions ofcubic } \\
\text { meters / year) }\end{array}$ \\
\hline Pendjari & Porga (2) & 22280 & 59.0 & 1861 \\
\hline Niger & Malanville & $(1000000)$ & 1006.0 & $(31725)$ \\
\hline Mékrou & Kompongou & 5700 & 18.5 & 583 \\
\hline Alibori (1) & Kandi-Bani & 8150 & 280 & 883 \\
\hline Sota (1) & Koubéri & 13410 & 32.3 & 1019 \\
\hline Ouémé & Bonou & 46990 & 172.0 & 5424 \\
\hline Couffo & Lanta & 1680 & 4.8 & 15 \\
\hline Mono & Athiémé (2) & 21475 & 101.0 & 3185 \\
\hline
\end{tabular}

Table I : Estimation of Surface Water Resources of Benin

Source: Reporton the national strategy of water resources management in Benin, 1997 andMinistry of Mining, Energy and Water, 2006

(*) Grand total (without Niger); (1) Affluent of Niger upriver from Malanville ; (2)International basins

The groundwater resources, through the annual total refill of the different aquifers are estimated at 1.87 billion of cubic meters, that is an average refill of 163 cubic meters per hectare over the areas considered. This water potential is threatened by decrease because of the exponential increase in consumptions and the downward tendencies of the atmospheric resources. Indeed, the quantity of the water, which is stored by the aquifers of the basin, drops depending on the rainfall recession related to the withdrawal of the monsoon. Consequently, the drying up speeds up, and having as consequence the reduction of the mobilized water (figure 2 ).
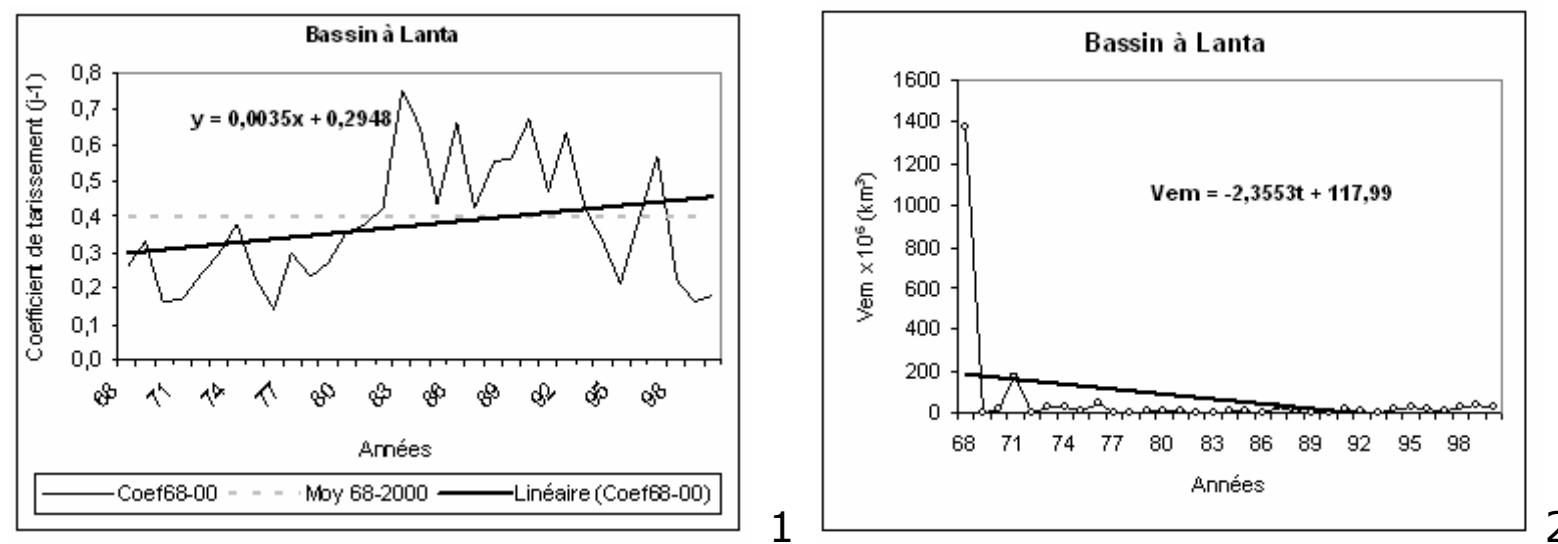

Picture 2: Variationof the drying up factor (1) and of the volume of the mobilized water (2) in the coastal sedimentary basin (Amoussou, 2005)

Table II shows that the coastal sedimentary basin, with $10 \%$ of the total area of the country, holds $32 \%$ of Benin ground water resources 


\begin{tabular}{|l|r|r|r|l|}
\hline \multicolumn{1}{|c|}{ Unit } & $\begin{array}{r}\text { Areas } \\
\text { (square } \\
\text { kilometre) }\end{array}$ & $\begin{array}{r}\text { Annual refill } \\
\text { (millions of } \\
\text { cubic meter) }\end{array}$ & $\begin{array}{c}\text { Refill } \\
\text { (cubic } \\
\text { meter } \\
\text { per } \\
\text { hectare) }\end{array}$ & \multicolumn{1}{|c|}{$\begin{array}{c}\text { Type of } \\
\text { aquifer }\end{array}$} \\
\hline Basement Area & 91800 & 1120 & 123 & Discontinuous \\
\hline $\begin{array}{l}\text { Sandstone of Kandi } \\
\text { basin }\end{array}$ & 10200 & 125 & 125 & Continuous \\
\hline $\begin{array}{l}\text { Coastal sedimentary } \\
\text { basin }\end{array}$ & 11303 & 600 & 500 & Continuous \\
\hline $\begin{array}{l}\text { Alluvial deposits of the } \\
\text { Niger and deposits of } \\
\text { the Pendjari basin }\end{array}$ & 1460 & 25 & 1250 & Continuous \\
\hline TOTAL & $\mathbf{1 1 4 ~ 7 6 3}$ & $\mathbf{1 ~ 8 7 0}$ & $\mathbf{1 9 9 8}$ & \\
\hline
\end{tabular}

Table II : Main geological units and aquifer refills in Benin

Source: Policy and strategy of water sector-MECAG-PDP, 1999 ; PNE, 2005

In Benin, people take and use surface and ground waters to satisfy their different household, agricultural, as well as industrial needs. However, the supplying of drinking water is often subject to some constraints, which make the access to this resource difficult.

\section{ACCESS TO WATER PROBLEMS}

Africa well illustrates the nature and extent of the problem that the global security of water supplying poses (Soliman, 2001). In Benin context, the constraints related to the access to water are manifold forms and are concerned with the quantitative as well as qualitative availability, and water resources governance.

The climatic picture of Benin (figure 2) shows a spatial variability of the rainfall and therefore an unequal distribution of water resources. The difficulty related to the access to water is more noticeable in areas where water resources are scarce or very limited. This is often related to a poor mobilization of rainwater due to the basins' shape and to groundwater drying up during the dry season. This is the case, for example, of the rivulets, or subsurface aquifers like the ones of the alterite layers of the crystalline basements areas of Benin. The populations are obliged to trek over very long distance (over $5 \mathrm{~km}$ ) to get a more or less drinking water mainly during the dry season or during the drought spell, which is far from WHO's norm, which considers that each individual has access to drinking water if he or she is served by a network or a pump less than 200 $\mathrm{m}$ from his or her house (Zérah, 1999). A person has an easy access to a quality drinking water if he/her gets water at home or within 15 minutes walk from her/his house (Nzuzi and Mbuyi, 2004). In this case, an individual has access to drinking water if he/she gets tap drinking water at home or nearby or at a distance that guarantees the quality of water during transportation. 


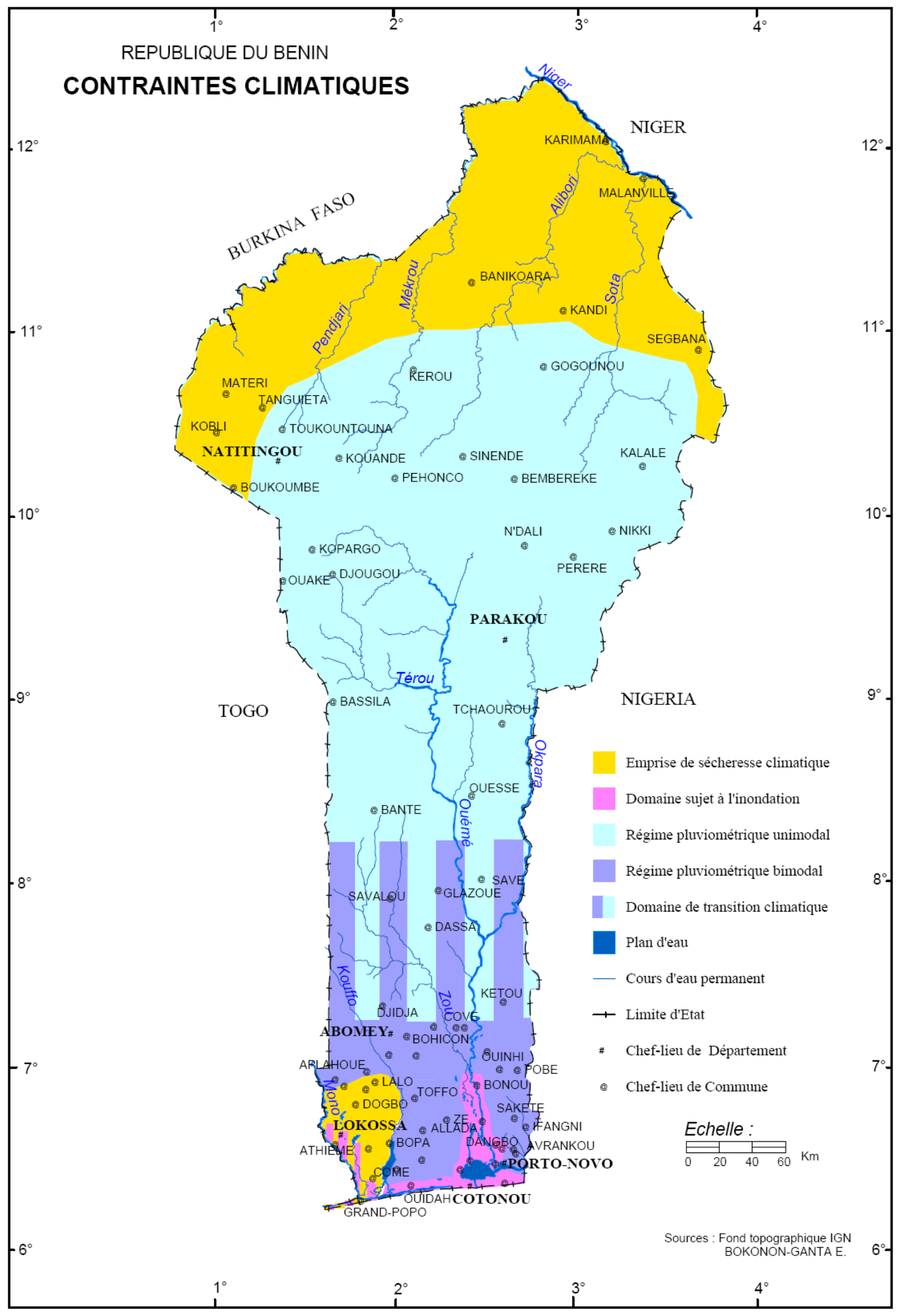

Figure 2: Map of climatic constraints in Benin

Source: MEHU, Initial Communication in Benin on Climatic Changes, 2001 and PANA, 2006 
The water scarcity is also due to the insufficiency of hydraulic equipments (wells, drillings, etc.), to the population growth, rapid urbanization, industrial development even slight, and to agriculture. The invasion of the watering places in the dry season (photo 1) illustrates human pressure, indicative of the scarcity of water during the dry season.

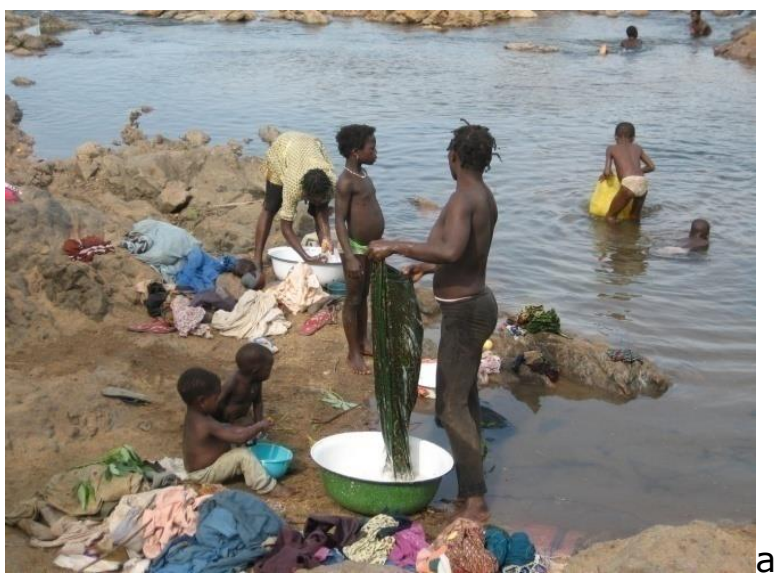

Negative: Amoussou Ernest, April 2007

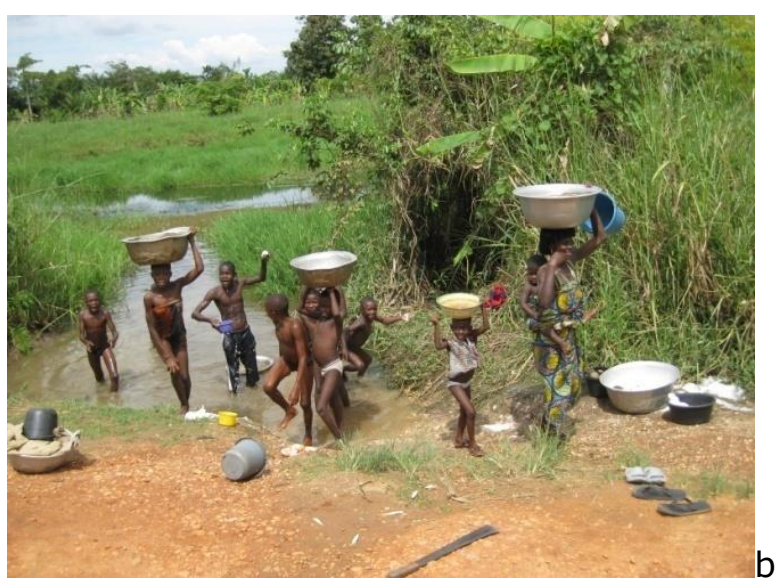

Negative: Totin V.S.Henri, October 2009

Photo 1. Multifunctional surface watering places in the dry season: Mono River at Adjarala, Aplahoué (a) and pond at Ouèdème Dékanmè (b)

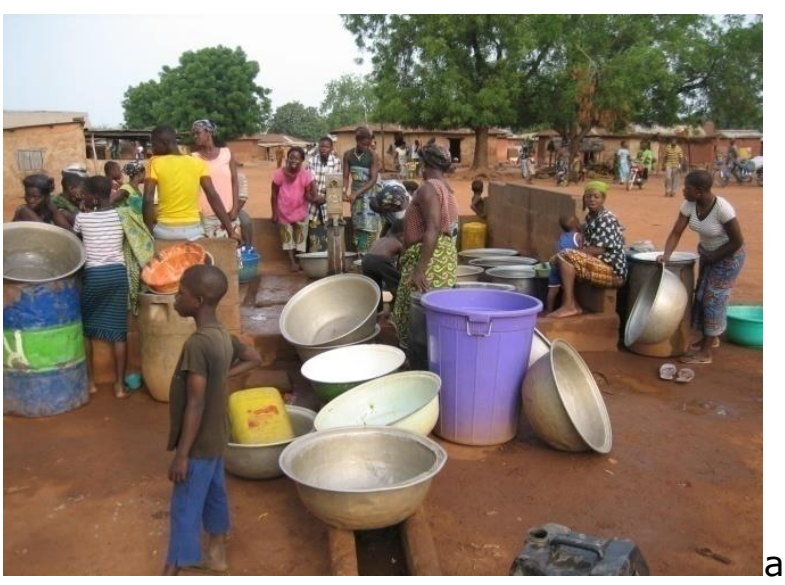

b

Negative: Gomez Ansèque, April 2007

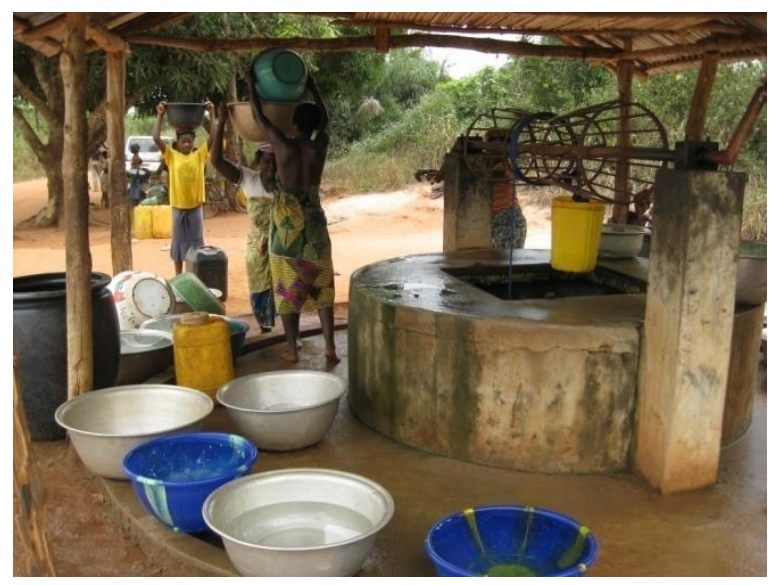

Negative: Totin V.S.Henri, January 2010

Photo 2. Supplying places of subterranean water invaded by the population in the dry season : drilling at Lougba at Bantè (a) and modern wells at Tori Avamè (b)

This situation is caused by the poor capacity of the water management services, such as the government water authority (DG-Eau) and Benin Water Company (SONEB) to supply all the rural and urban populations with water and to meet the demand.

In addition, the high cost of water is today a problem of access because of the increase in the mobilization and treating expenses. The prohibitive purchasing and extension costs of the water conveyance networks exclude the poor and those with weak incomes, who are obliged to resort to contaminated or non suitable water for human consumption, or to pay-back water from subscribers at a rate of $500 \%$ of the basic price..

Groundwater and surface waters are, more and more subject to chemical and biological pollution. This pollution is caused by urbanization and by a great concentration of the populations in areas where ground water table is not deep, and also by uncontrolled and 
mis-use of chemical fertilizers and pesticides (Yèhouénou, 2006). According to Odoulami (2009), the populations of Cotonou do not have an easy access to drinking water; moreover, the water resources of Cotonou are in general polluted by wastes from the city and by the release from agricultural inputs drilled from the north to the south of Benin by river flow and running waters.

It is in such a tough context that climate change issues emerge, which will, obviously, worsen and complicate the problems of access to water.

\section{IMPACTS OF THE CLIMATIC CHANGES ON WATER RESOURCES}

The surface and ground watering places are sensitive to the climatic variability and as result to climatic changes. According to GIEC report (2007), the impact of the climate changes on water resources will be marked by the decrease in the available resources due to drought vents in the middle latitudes and in semiarid areas of low latitudes. Table III recaps the potential effects of the climatic changes on water resources.

\begin{tabular}{|c|c|c|}
\hline $\begin{array}{c}\text { Phenomenon }{ }^{a} \text { and early } \\
\text { evolution }\end{array}$ & $\begin{array}{l}\text { Probability of future } \\
\text { evolution according to } \\
\text { forecasts established } \\
\text { for the } 21^{\text {st }} \text { century of } \\
\text { the basis of SRES } \\
\text { scenarios }\end{array}$ & Water resources \\
\hline $\begin{array}{l}\text { Cold days and nights less } \\
\text { numerous and less cold, } \\
\text { hot days and nights more } \\
\text { numerous and hotter, over } \\
\text { most of the emergedlands }\end{array}$ & Practically sure ${ }^{b}$ & $\begin{array}{l}\text { Effects on water resources } \\
\text { reliant on snow melting; } \\
\text { effects on some supplying } \\
\text { springs }\end{array}$ \\
\hline $\begin{array}{l}\text { Periods or heat waves } \\
\text { more frequent on most of } \\
\text { the emerged lands }\end{array}$ & Very likely & $\begin{array}{l}\text { Increase in the demand; } \\
\text { problems related to the } \\
\text { quality of the water } \\
\text { (proliferation of seaweeds, } \\
\text { for example) }\end{array}$ \\
\hline $\begin{array}{l}\text { Heavy rainfall more } \\
\text { frequent in most of the } \\
\text { regions }\end{array}$ & Very likely & $\begin{array}{l}\text { Harmful effects on the } \\
\text { quality of surface and } \\
\text { subterranean water; } \\
\text { contamination of the } \\
\text { supplying springs; possible } \\
\text { softening of the lack of } \\
\text { water }\end{array}$ \\
\hline $\begin{array}{l}\text { Increase indrought event } \\
\text { occurrence }\end{array}$ & Likely & Increase in water stress \\
\hline $\begin{array}{l}\text { Increase in intense } \\
\text { cyclonic activity }\end{array}$ & Likely & $\begin{array}{l}\text { Disturbance of water } \\
\text { supplying in times of } \\
\text { blackouts }\end{array}$ \\
\hline $\begin{array}{l}\text { Increased effects of the } \\
\text { raising episodes of the } \\
\text { extreme level of the sea } \\
\text { (except for the tsunamis) }^{c}\end{array}$ & Likely ${ }^{d}$ & $\begin{array}{l}\text { Diminishing of the quantity } \\
\text { of the available fresh water } \\
\text { due to the intrusion of salt } \\
\text { water }\end{array}$ \\
\hline
\end{tabular}

Table III: Examples of possible effects of the meteorological and extreme climatic events associated with climatic changes, according to forecasts aiming at the second half of the $21^{\text {st }}$ century. The evolution of the adaptation capacity has been taken into account.

Source : GIEC, 2007 


\section{Notes :}

a) The exact definitions are given in table 3.7 of the work group I.

b) Raising of the extreme values of the diurnal and nocturnal temperature recorded yearly

c) The extreme sea level rise depends on the average level of the sea and on the regional meteorological systems. It corresponds to the higher level (1\%) of the hourly values recorded at a given station in a reference period.

d) In all the scenarios, the average level of the sea in 2010 is higher to the one of the reference period. The effects of the evolution of the regional meteorological systems on the episodes of extreme sea level rise have not been taken into account.

The studies conducted by the Intergovernmental Panel for Climate Change suggest that the rainfall amount should still drop in the areas which are already arid in East and South Africa, and in the North and Central Africa, thus worsening drought and desertification. In West Africa, water shortage should affect Benin, Burkina Faso, Ghana, Mauritania, Niger, and Nigeria by 2025.

The research work conducted in the different areas of Benin on climate, surface and ground water resource issues(Gbatcho, 1992 ; Boko, 1998 ; Boukari, 1998, Linsoussi, 2000 ; Sadji, 2004 ; Amoussou, 2003 and 2005 ; Totin, 2003 and 2005 ; Tossa, 2005 ; Vissin et al., 2006 ; Vissin, 2001 and 2007 ; Boukari and Alassane, 2007 ; Idiéti, 2009, Totin, 2009) show the break occurred in the hydro-climatic chronicles in the seventies and indicate a downward trend in surface water resources, twice to, four times more important than the one of the rainfall amount in the main watersheds. Furthermore, the aquifers show a refill gap of the ground water (Boukari, 1998; Totin, 2005), and a variation of the hydro-chemical components (Alassane, 2004).

Should this climatic and hydrological trend keeps steady, the hydrological drought would lead to a significant decrease of water resources and to a risk of shortage. Likewise, the quality of waters will be affected variously. The very humid climatic events, would result in the intensification of pollutants transfer to water reservoirs, contrary to the drought events that would intensify the deterioration of the quality of water resources, mainly bacteriological quality,.

Besides, the community natural water springs supply, made up by surface and ground waters, will decrease to some extent and the populations will resort to transport, storage, and drillings. The cost of the activities of transport, of the equipped drillings achievement will be a restrictive factor and as a result, the supplying will certainly not be sufficient, and shifts in population to gather around perennial watering places, and a rural exodus leading people to urban areas must be expected. The impacts of the climate changes on water resources are detrimental to supplying systems and to the satisfaction of the needs of the populations, particularly the poor. 


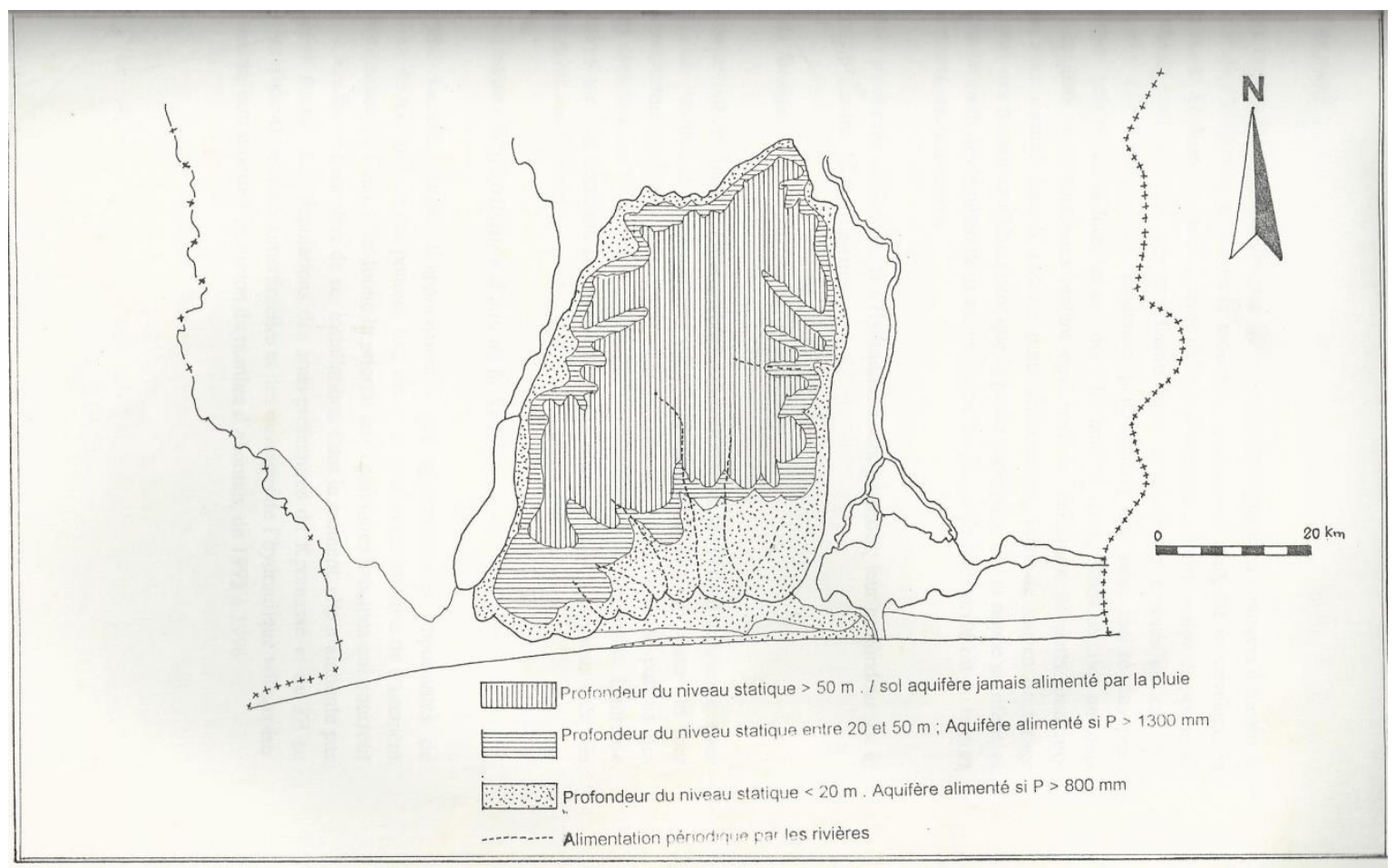

Figure 4: Depth and refill of subsurface aquifers in the coastal sedimentary basin of Benin. (Source : Géodynamique, 1985 cité par Sèdjamè, 1998)

\section{6- SOLUTIONS AND PERSPECTIVES}

The corrective measures and the mitigation strategies of the impacts of the climate change on water resources are a better insight into the water systems sensibility. In addition, it is worthwhile implementing integrated management policies of water resources according to the climatic specificities of each region of Benin.

Facing the quantitative and qualitative deterioration of waters, both surface and ground water, one should develop strategies helping increase potentialities of the resource availability. For this purpose, it is important to protect areas of ground water recharge. The improvement of water resource quality in the context of climate change implies that the population must be sensitized over the risks of shortage and on the good practices in agricultural production (chemical fertilizers and pesticide use)and waste management.

In addition, there is a wide range of adaptation strategies and management of the impacts of the climate changes on water resources in Benin. Among these strategies, one can cite:

i. the build-up of new dams (to regulate all the resources, still available) and water transfer (between surplus basins and the ones in deficit);

ii. Identification of subterranean waters namely the ones of deep aquifers not yet exploited;

iii. the purification of waste water, before their discharge in the natural environment, would help to improve the quality of receiving places (namely the one of watercourses);

iv. the improvement of the output of the water conveyance networks and the distribution of drinking water up to $80 \%$ helping to save several millions of cubic meters of water the year.

Thus, water code must be adapted to the context of climate changes and to the resource vulnerability. 
Moreover, the government has to set up the National Authority of Water and of Sanitation for the integrated management of water nationwide by extending its responsibilities to the hydrological basin level. The sustainable water management also has to go through a rational use of the resource so as to limit wasting through abusive and not very necessary uses.

\section{7- CONCLUSION}

At the hydrological level, Benin is sufficiently endowed with water whether surface water or ground water, but they are irregularly shared out spatially and temporally. The régime of waters is quite related to rainfall one. The more the climate is changing, so is the hydrological régime.

The climate change will have a great impact on water resources in Benin. If nothing is done to reduce the effects of climate warming, this will be a disaster, especially for the poor. The impacts of the climate change on water resources are already noticeable in Benin at the level of surface and ground water systems. The rainfall decrease results in a decrease in water resources, which will worsen the access difficulties to drinking water whose purchasing pricealready prohibitive to the poor will be higher.

The implementation of a operational and efficient management plan of surface and ground resources, integrating all the aspects of climate changes and of the vulnerability of water systems is essential.

\section{REFERENCES}

Afouda A., Ould Baba Sy M., Gaye A. T., Cabral A., Nazoumou Y., Compaoré J. A., Sanoussi R., 2007. Impacts du changement et de la variabilité climatiques sur les ressources en eau des bassins versants Ouest Africains : Quelles perspectives ? In : Adaptation aux changements climatiques et gestion des ressources en eau en Afrique de l'ouest. Rapport de synthèse de Writeshop, Dakar 21-24 février, pp. 23-31.

Alassane A., 2004. Etude hydrogéologique du Continental terminal et des formations de la plaine littorale dans la région de Porto-Novo (Sud du Bénin) : Identification des aquifères et vulnérabilité de la nappe superficielle. Thèse de Doctorat du 3ème cycle. Université Cheikh Anta Diop, Dakar, 145 p. + annexes.

Amoussou E. 2005. Variabilité hydro-climatique et dynamique des états de surface dans le bassin versant du Couffo. Mémoire de DEA, EDP/FLASH-UAC.104 p.

Amoussou $E .$, 2003. Dynamique hydro-sédimentaire et mutation des écosystèmes du 'lac' Ahémé. Mémoire de maîtrise, DGAT/UAC.101 p.

Boko M., 1998 Climat, eau et société au Bénin. In Annales de la FLASH, UAC. 50 p.

Bonell M., 2001. La variabilité climatique et l'évolution de l'hydrologie et des ressources en eau dans le cadre de la politique de gestion: Une perspective du PHI de I'UNESCO. In : Les ressources en eau de I'Afrique. Gash C.H.J., Odada O.E., Oyébandé L., Schulze E.R. (éditeurs). Nairobi, Kenya. pp. 131-141.

Boukari M. et Alassane A., 2007. Les ressources en eau du bassin sédimentaire côtier de la République du Bénin. Africa Geoscience Review, (14)3 : 283-301. 
Boukari M., 1998. Fonctionnement du système aquifère exploité pour I'approvisionnement en eau de la ville de Cotonou sur le littoral béninois. Impact du développement urbain sur la qualité des ressources. Thèse de Doctorat d'Etat. UCAD, Dakar, 278 p. + annexes.

FAO, 1987. Irrigation and water resources potential for Africa. Rome.

Gadelle F., 1995. Le monde manquera-t-il bientôt d'eau ? In : Sécheresse. $\mathbf{N}^{\circ} \mathbf{1}$ (6) pp. 9-14.

Gbatcho A. M., 1992. Contribution à l'étude des rythmes pluviométriques et hydrologiques du bassin de l'Ouémé au pont de Savè. Mémoire de maîtrise de géographie, DGAT/UAC. $69 \mathrm{p}$.

GIEC, 2007 : Bilan 2007 des changements climatiques. Contribution des Groupes de travail I, II et III au quatrième Rapport d'évaluation du Groupe d'experts intergouvernemental sur I'évolution du climat [Équipe de rédaction principale, Pachauri, R.K. et Reisinger, A. (publié sous la direction de )]. GIEC, Genève, Suisse, ..., $103 \mathrm{p}$.

Idiéti E. M., 2009. Variabilité hydro-climatique dans le bassin versant de la Pendjari (Nord-Ouest du Bénin). Mémoire de DEA, Université d'Abomey-Calavi, Cotonou, Bénin, $94 \mathrm{p}$.

Issar A.S., 1995. Impacts of climate variableness on water management and related socio-economic systems. Technical Documents in Hydrology, IHP, UNESCO, Paris, $97 \mathrm{p}$.

Linsoussi A. C., 2000. Evaluation des risques climatiques en matière de gestion des ressources en eau : contribution à la caractérisation événementielle des régimes ouestafricains et de leur fluctuation. Thèse d'ingénieur agronome, FSA/UAC. 59 p.

MEHU, 2001. Communication Nationale Initiale du Bénin sur les Changements Climatiques. Cotonou. $75 \mathrm{p}+$ annexes.

MMEE, 2006. Etude des systèmes de gestion / utilisation de l'eau et définition des actions prioritaires de valorisation locale des ressources eau dans une approche gire au Bénin. Volume 1 - Etat des lieux de la gestion des ressources en eau du Bénin. Rapport technique, Cotonou, $121 \mathrm{p}$.

Nzuzi F. L. et Mubuyi C. T., 2004. Pauvreté urbaine à Kinshasa, éd. Cordaid, La Haye, $166 \mathrm{p}$.

Odoulami L., 2009. L'eau dans la ville de Cotonou. Thèse de doctorat, Université d'Abomey-Calavi, Cotonou, Bénin, 223 p.

PANA, 2006. Recueil des informations et des documents existants sur les effets néfastes des Changements Climatiques en République du Bénin. MEHU, Cotonou, Bénin, $57 \mathrm{p}$.

Sadji Boukari A., 2004. Vulnérabilité/adaptation des ressources en eau de surface aux changements climatiques dans le département de la Donga. Mémoire de maîtrise, DGAT/UAC. 81 p.

Soliman R. W., 2001. Le défi africain du millénaire : la gestion des ressources en eaux de la Banque Africaine de Développement. In : Les ressources en eau de I'Afrique. Gash C.H.J., Odada O.E., Oyébandé L., Schulze E.R. (éditeurs). Nairobi, Kenya. Pp. 27-32. 
Tossa A., 2005. Changements climatiques et dynamique hydrologique au Bénin. Mémoire de DEA, EDP/FLASH, UAC.78 p.

Totin H. V. S. 2005. Tendances hydroclimatiques et scénarios de gestion des ressources en eau sur les plateaux du sud-Bénin. Mémoire de DEA EDP/FLASH UAC.80 p.

Totin V. S. H., 2003. Changements climatiques et vulnérabilité des ressources en eau sur le plateau d'Allada : approche prospective. Mémoire de maîtrise de géographie. DGAT/UAC. $105 \mathrm{p}$.

Totin V. S. H., 2009. Variabilité hydroclimatique et disponibilité en eau de surface dans le bassin béninois de la Volta. Rapport de recherche de IFS, Cotonou, Bénin, 85 p.

Vissin E. W., 2001. Contribution à l'étude de la variabilité des précipitations et des écoulements dans le bassin béninois du fleuve Niger. Mémoire de DEA, Université de Bourgogne, Dijon. $49 \mathrm{p}$.

Vissin E. W., 2007. Impact de la variabilité climatique et de la dynamique des états de surface sur les écoulements du bassin béninois du fleuve Niger. Th. de Doct. de I'Univ. de Bourgogne, Dijon, France, 5210, 280 p.

Vissin E. W., Houssou C. S., Houndénou C., 2006. Péjoration pluviométrique et vulnérabilité des écoulements dans le bassin béninois du fleuve Niger. " Sciences de l'Environnement", LaRBE, Lomé. pp. 75-92.

Zérah M.H., 1999. L'accès à l'eau dans les villes indiennes, éd. ECONOMICA, coll. VILLES dirigée par Denise Pumain, $168 \mathrm{p}+$ annexes. 